\title{
Unintended consequences: the EU memory framework and the politics of memory in Serbia and Croatia
}

\section{Ana Milošević \& Heleen Touquet}

To cite this article: Ana Milošević \& Heleen Touquet (2018): Unintended consequences: the EU memory framework and the politics of memory in Serbia and Croatia, Southeast European and Black Sea Studies, DOI: 10.1080/14683857.2018.1489614

To link to this article: https://doi.org/10.1080/14683857.2018.1489614

Published online: 08 Aug 2018.

Submit your article to this journal $\sqsubset$

Џ Article views: 40

View Crossmark data $\complement$ 


\title{
Unintended consequences: the EU memory framework and the politics of memory in Serbia and Croatia
}

\author{
Ana Milošević (iD) ${ }^{a}$ and Heleen Touquet $\mathbb{D}^{\mathrm{b}}$

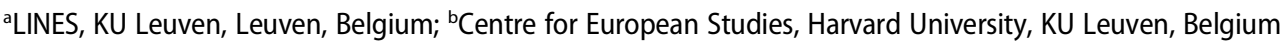

\begin{abstract}
The shared memories of the Second World War have played a crucial role in the process of integration of the European Union (EU). After the Enlargement to the East, the EU also sought to accommodate the historical experiences of the former communist countries. The result of this process was an EU memory framework that focused on shared suffering under totalitarian (both fascist and communist) regimes. This article examines the impact of this framework and its equalization of fascism and communism on Croatia (new member state) and Serbia (in accession talks). We conclude that the framework is used locally as an opportunity structure to renegotiate ideological conflicts.
\end{abstract}

\section{ARTICLE HISTORY}

Received 30 Aug 2017

Accepted 25 Apr 2018

\section{KEYWORDS}

Europeanization; memory; totalitarianism; communism; Serbia; EU; Croatia

\section{Introduction}

Collective memory is a central aspect of the formation of modern nation-states, as memories are crucial elements that can help define and strengthen group identity (Anderson 1983; Connerton 1989). Given memories' deep connections to societies' cultural codes and myths (Hobsbawn and Ranger 1983; Assmann 2008), they can become powerful tools for collective mobilization. Political elites instrumentalize the past for particular purposes: to put a troubled past to rest, or in order to frame a particular future. In this sense, political elites function as memory entrepreneurs: 'those who seek social recognition and political legitimacy of one [their own] interpretation or narrative of the past, engaged and concerned with maintaining and promoting active and visible social and political attention on their enterprise' (Jelin 2003, 33-34).

The process whereby political elites seek legitimacy for their interpretation of the past takes place at both the national and the transnational levels. In Europe, the European Union (EU) is one of the central venues for the uploading, dissemination and formation of collective memories and identities. Whilst the EU started out as a project of mainly economic cooperation, it also focused from the beginning on the reconciliation of the former warring parties in mainland Europe (i.e., France and Germany). The negative memory of the Holocaust anchored the unification project in history and aimed to promote the development of a collective (Western) European identity (Probst 2003; Leggewie 2008; Pakier and Strath 2010; Littoz-Monett 2012; Kucia 2016).

CONTACT Ana Milošević $\otimes$ ana.milosevic@kuleuven.be $=$ KU Leuven, Parkstraat 45, 3000 Leuven, Belgium. (c) 2018 Informa UK Limited, trading as Taylor \& Francis Group 
The end of the Cold War was a crucial turning point that forced the EU to expand the European collective memory framework to a more general interpretation of shared suffering under totalitarian (both fascist and communist) regimes after the accession of former communist countries in 2004 (Neumayer 2015; Mink 2016).

We use the term 'the EU memory framework' to refer to the collection of policies, resolutions and decisions by the European Commission and the European Parliament (EP) that reflect and guide collective moral and political attitudes towards the past (for an overview, see Table 1). The EP produced a significant number of resolutions dealing with the past over the last three decades and plays the most central role in the development of the framework (Milošević 2017). These documents discuss joint remembrance practices and offer symbolic acknowledgment for the victims to whom that right has been denied in the past. On the one hand, memory policies redress the past; on the other hand, they function as a form of soft power and express collective attitudes and political positions. One example of a resolution that was meant to redress past injustices was the EP resolution on the commemoration of the Roma Holocaust (EP 2015a). In the words of the Parliament:

Table 1. The EU memory framework.

\begin{tabular}{|c|c|}
\hline \multicolumn{2}{|c|}{ The EU enlargement process and key decisions of the European Parliament regarding historical memory, 1986-2016 } \\
\hline EU enlargement & Adoption date/Resolution \\
\hline \multirow{2}{*}{$\begin{array}{l}1958 \\
\text { Foundation of the EU } \\
\text { community }\end{array}$} & $\begin{array}{l}\text { As an elected body, the Parliament began to draft proposals addressing the functioning of the EU only } \\
\text { after } 1979\end{array}$ \\
\hline & 06/1986 European Parliament, Council and Commission Declaration against racism and \\
\hline$\downarrow$ & xenophobia \\
\hline 1973 & 07/1987 Armenian Genocide \\
\hline Denmark & 10/1987 Le Pen and the Holocaust \\
\hline Ireland & 02/1993 Nazi concentration camps as historical monuments \\
\hline United Kingdom & 07/1995 Holocaust Remembrance Day \\
\hline \multirow{2}{*}{$\downarrow$} & $12 / 1995$ Resolution on the return of plundered property to Jewish communities \\
\hline & 04/1996 Resolution on Auschwitz \\
\hline Greece & 07/1998 Resolution on restitution of the possessions of Holocaust victims \\
\hline & 03/2000 Resolution on countering racism, xenophobia and anti-Semitism in the candidate \\
\hline 1986 & countries \\
\hline Spain & 06/2000 Declaration on the remembrance of the Holocaust \\
\hline Portugal & $01 / 2005$ Remembrance of the Holocaust, anti-Semitism and racism \\
\hline$\downarrow$ & 05/2005 The future of Europe 60 years after the Second World War \\
\hline 1995 & 06/2005 Declaration on Srebrenica \\
\hline Austria Finland & 09/2005 Solidarność \\
\hline Sweden & 10/2006 50th anniversary of the 1956 Hungarian Revolution and its historical meaning for \\
\hline & Europe \\
\hline 2004 & 05/2007 On Estonia \\
\hline \multirow{2}{*}{$\begin{array}{l}\text { Czech Republic } \\
\text { Estonia }\end{array}$} & 09/2008 Proclamation of 23 August as European Day of Remembrance for Victims of \\
\hline & Stalinism and Nazism \\
\hline Cyprus & 10/2008 Holodomor remembrance \\
\hline Latvia & 01/2009 Declaration on Srebrenica \\
\hline Lithuania & 04/2009 European conscience and totalitarianism \\
\hline Hungary & $11 / 2009$ European Day of Reconciliation \\
\hline Malta & 2010 European Commission: The memory of the crimes committed by totalitarian regimes \\
\hline Poland & in Europe \\
\hline Slovenia & 03/2013 Strengthening the fight against racism, xenophobia and hate crime \\
\hline Slovakia & 11/2014 Serbia: the case of accused war criminal Šešelj \\
\hline & 01/2015 Recognition by Turkey of the 1915 Armenian genocide \\
\hline \multirow{2}{*}{$\begin{array}{l}2007 \\
\text { Bulgaria }\end{array}$} & 04/2015 International Roma Day - anti-Gypsyism in Europe and EU recognition of the \\
\hline & Memorial Day of the Roma genocide during WW II \\
\hline Romania & 04/2015 Armenian genocide 100th anniversary \\
\hline \multirow{3}{*}{$\begin{array}{l}\downarrow \\
2013 \\
\text { Croatia }\end{array}$} & 07/2015 Srebrenica commemoration \\
\hline & \\
\hline & \\
\hline
\end{tabular}


The genocide of Roma by the Nazi and other regimes and their allies during World War II is a fact that is still largely ignored and is therefore not acknowledged by the broader public and often not recognized or taught in schools, thus placing Roma people among the 'ignored' victims of the genocide during World War II. (EP 2015a, Recital K)

Perhaps more importantly, EP resolutions also aim to exert pressure on third-countries to comply with their own provisions and decisions or to influence their foreign policy. The resolutions on the Armenian genocide invited Turkey 'to come to terms with its past, to recognize the Armenian Genocide and thus to pave the way for a genuine reconciliation between the Turkish and Armenian peoples' (EP 2015b, Article 5). When a monument to the liberators of Talinn was dismantled and riots broke out in Tallin and Moscow (see Roth 2009), the EP condemned Russian foreign policy in a resolution (EP 2007).

In this article, we seek to analyse the impact of the European memory framework on the politics of memory of two post-conflict states: Croatia and Serbia. We examine how the framework is interpreted and utilized by political elites in the process of EU Integration, focusing in particular on how national historical experiences of the Second World War (WWII) and its aftermath are interpreted. The article is divided into three parts. The first section analyses the place of collective memories and identities in the process of Europeanization and EU accession. Next, we zoom in on the development of the politics of memory in (the former) Yugoslavia, and on the role of collective memories in the nationand state-building processes of post-independence Croatia and Serbia. In the third part, we analyse if and how anti-totalitarian policies, politics and discourses are used in the accession process. The analysis is based on documents, resolutions, memory policies on both the European and national level. We also draw on 40 elite-interviews with members of the EP (2013-2017) as well as national political elites such as former presidents, former presidents of the EP and the EU Commissioner for the Enlargement. In addition, we also use field notes of the 2017 commemoration at the former WWII concentration camp in Jasenovac, Croatia.

\section{The EU memory framework: from Holocaust to anti-totalitarianism}

The EU memory framework evolves continuously as it is reinterpreted and adapted. On the one hand, the EU disseminates its memory policies and practices to candidate and potential candidate countries. On the other hand, new member states also try to influence the framework, by uploading memories they see as crucial for their national identity and their identity as an EU member state. The EP is the main arena for uploading domestic memory discourses, policies and practices, with the members of the European Parliament (MEP) in a key role in the promotion and integration of domestic memories into the European memory framework. In the process, ideological tensions within and among the member states are assuaged (see Mink 2016). National memories that get integrated into the EU memory framework become situated in a broader historical context and get a symbolic recognition (see Montero 2010). For example, the EP adopted a resolution on the 1956 Hungarian uprising and its historical meaning for Europe 'recognizing that the Hungarian Revolution was a historic attempt at the reunification of a divided Europe, and as such remains a cornerstone of our common European historical heritage' (EP 2006, Recital K). This resolution was one of the first East European memories integrated into the expanding EU memory framework. Yet, memory-entrepreneurship in the EP reaches 
beyond the confines of the history of EU member-states to candidate countries and countries in the so-called EU Neighbourhood. The Armenian genocide, ${ }^{6}$ Holodomor $^{7}$ in Ukraine or even more recent, the Srebrenica genocide ${ }^{8}$ in Bosnia-Herzegovina were all subjects of EP resolutions over the last decade.

While this memory framework is not part of EU conditionality for acceding states, the EP exerts soft pressure to align with its resolutions and decision as a prescribed model. For example, the last paragraph of the Resolution on Srebrenica (see EP 2009a) explicitly instructs the president of the EP to forward the resolution to the governments of the Western Balkan states as a way of encouraging them to follow suit. By targeting non-members (candidate and potential candidate countries) as recipients of these policies, potential member states and candidate countries are stimulated to 'download' EP memory policies as means of aligning and confirming their EU values, and thus European identities. ${ }^{9}$

Our analysis focuses on a central turning point in the development of the EU memory framework: the end of the Cold War and the accession of the Eastern European member states. These developments prompted a revision of the past, spurred on by the memories of communism that came to the surface in Eastern Europe. How Western Europe remembered its own rebirth from the ashes of WWII was in stark contrast with experiences of countries behind the Iron Curtain.

The memory of the Holocaust was the original founding pillar of post-war Europe, centring on common values and principles such as anti-Semitism and the rejection of racism and xenophobia. While Germany assumed collective responsibility for the horrors of the WWII, for the rest of Western Europe it was a convenient means to divert attention from their own wartime collaboration and the often far less glorious history of national resistance than official accounts tended to portray (Prutsch 2013, 25). For Central and Eastern Europe and the Baltic states by contrast, the end of the WWII was not perceived as a liberation, but as the beginning of another tyranny (see e.g., Jambrek 2008). In the process of dealing with the different interpretations of the European past, an adapted EU memory framework emerged, as these countries 'uploaded' their own memories of oppression under the communist and Stalinist regimes as new EU members.

The process of uploading new memories started outside of the institutions of the EU in the Council of Europe (CoE) (see Rostoks 2011). The council has often served as a laboratory for later evolutions within the EU (see Calligaro and Foret 2012). In January 2006, the CoE adopted the Resolution on the necessity to condemn totalitarian communist regimes. It framed the condemnation of communism as a 'moral obligation' of the international community 'to take a clear stance towards communist regimes and their legacies enabling thus the paths towards reconciliation among European peoples' (CoE 2006). The resolution was supported by the European People's Party, liberal parties and social democrats mainly coming from countries as Hungary, the Czech Republic and the Baltic countries but strongly opposed by leftist parties. ${ }^{10}$ Despite a low turnout, the resolution was adopted with 99 votes for, 42 against and 12 abstentions (see PACE Assembly 2006). A similar voting pattern could later be observed in 2008 and 2009 when the EP adopted two anti-totalitarian resolutions.

The Slovenian Presidency of the EU promoted the idea of a shared memory of the crimes committed by totalitarian regimes across the EU in 2008 in a hearing it organized with the European Commission. ${ }^{11}$ In the wake of this meeting, an informal group of the EP called 
Reconciliation of European histories was formed to address 'the challenge of including the experience of the post-communist nations into the common narrative of European History $^{12}$ (see Neumayer 2015). This common approach to the authoritarian and totalitarian regimes of the twentieth century was soon institutionalized by the EP: first through the adoption of 23 August as the 'European Day of Remembrance for the Victims of all Authoritarian and Totalitarian Regimes' (EP 2008) and then with resolution on 'European Conscience and Totalitarianism' (EP 2009b). These documents frame the process of European integration as an answer to the sufferings inflicted by Nazism, fascism, communist and Stalinist regimes. In addition, they demand, among other things, 'a comprehensive revaluation of European history' prescribing that

Europe will be united only when it is capable to reach a common point of view on its history, recognize communism, Nazism and fascism as collective legacy and lead an honest and thorough debate on all totalitarian crimes of the last century. (emphasis ours) (EP 2009b, recital H)

This equalization of Nazism and Communism created ideological struggles over the interpretation of WWII and its aftermath. Debates were held not only in the EP. Intellectuals and academics from different European countries warned that anti-totalitarianism could lead to a 'de-contextualization with no foreseeable consequences, at the price of erasing clear historical causality and indisputable responsibilities' (Morsch 2012, 128; Kuljić 2011; Coromines i Guixe 2016; Katz 2015).

How have these resolutions and their equalization of Nazism and Communism affected the countries Western Balkans and the way they deal with their histories of the WWII?

\section{The politics of memory in the former Yugoslavia}

In order to examine the impact of EU's anti-totalitarian consensus on the countries of the former Yugoslavia, we briefly discuss the Yugoslav narrative of the WWII and the controversies associated with it.

In the former Yugoslavia (1945-1991), the politics of memory was used to support the state- and nation-building process after the war (see Jović 2004, 2009). It relied upon symbolism from the popular struggle for liberation from Nazism and fascism (narodnooslobodilacka borba - NOB). The core of these processes was the narrative of 'brotherhood and unity' (bratstvo i jedinstvo) which served to pacify ethnic tensions after the WWII. Parts of the population had supported and collaborated with the Nazi and fascist regimes, while others fought them seeking liberation. Yet, only one dimension existed in official Yugoslav memory - the war as a 'national liberation war and a socialist revolution (narodnooslobodilački rat i socijalna revolucija)' (Djokić 2002, 132).

The official narrative of WWII in Yugoslavia marginalized the experiences of the nationalist movements that collaborated with the Axis. In Croatia, Italians and Germans helped the Ustaša, the Croat fascist movement, to establish the Independent State of Croatia (NDH) 1941-1945 - a Nazi-puppet state. The Ustaša ran death camps on their own territory already in the summer of 1941 - inspired by the national socialists but operated on their own (Radonić 2012, 205; Frucht Levy 2009). The most notorious of all camps was Jasenovac, where besides Croatian anti-fascists, Roma and Jewish victims, the largest number of victims were Serbs (see Karge 2009). In Serbia, after the Germans, Italians and 
Hungarians invaded Yugoslavia in April 1941, the remaining detachments of Royal Yugoslav army regrouped ${ }^{13}$ in the Četnik movement led by Dragoljub Mihailović. In the beginning, the Četniks fought the Axis powers, later they also collaborated with them in fighting the Ustaša and Partisans. The Partisan resistance against the Axis, Ustaša and Četniks was a multi-ethnic movement, led by the communists.

In the final months of the war and in the immediate post-war period, the communists liquidated thousands of real or suspected collaborators and so-called class enemies. While the Ustaše stayed loyal to Hitler until the end, much of their leadership was able to escape to the West and Latin America after May 1945 (Pavlaković 2008). Tens of thousands of others associated (or allegedly associated) with the regime suffered in post-war communist massacres, death marches and other types of persecution. In Croatia, these events are symbolically remembered through the commemoration of the Bleiburg massacre (see e.g., Ravančić, Martina 2009; Pavlaković 2010). While fleeing Yugoslavia, a number of soldiers and civilians associated with the Axis were killed or imprisoned near Austrian village of Bleiburg. ${ }^{14}$ In addition, the communist regime expelled and in some instances killed local Hungarian and German populations living in Vojvodina (Serbia) and Slavonia (Croatia), who were seen as sympathizers and collaborators of 'domestic and foreign enemies' (see e.g., Langenbacher 2003; Niebuhr 2016).

In the 1980s, nationalist movements mobilized memories of these events to discredit the Yugoslav communist regime, often relativizing the crimes committed by Ustaša and Četniks (Kuljić 2006). Many regional historians supported this nationalist competition in victimhood as they sought to paint their own nation as the 'greatest victim' but above all, the victim of the 'Other'. ${ }^{15}$ As Djokić (2002) explains,

in the late 1980s and early 1990s, most Serbs did not seek reconciliation with Croats but with other Serbs of different ideological persuasion and vice versa - right-wing Croats sought to harmonize relations with left-wing Croats, rather than with Serbs in general or at least with Croatia’s Serb minority.

In Serbia, Slobodan Milošević became the incarnation of the ethno-nationalism that had been gaining momentum since the early 1980s. Milošević's Gazimestan speech (Milošević 1989), held during a rally to mark the 600th anniversary of the 1389 Kosovo battle, illustrates the core elements of Serbian nationalism in the 1990s. It evokes 'the historical trauma' of the Kosovo battle as an important marker of Serb national identity, with the Serb people as heroic victims defending Europe's culture and values against Turkish/Islamic invasion. However, Milošević's ethno-nationalism unintentionally opened the door for legal and symbolic acts aiming to rehabilitate the Četniks - to restore the former privileges and the reputation of the movement, and its members prosecuted or exiled during the communist Yugoslav period. Paradoxically, Milošević who is often portrayed as a unifier of the Serbian people abstained from calls for national reconciliation, unlike the right-wing parties in the opposition. By summer 1990, there were two political parties endorsing the Četnik ideology of 'Greater Serbia' - a state for all Serbs in the region: the Serbian Renewal Movement (Srpski pokret obnove - hereafter SPO) and the Serbian Četnik Movement (Srpski Četnički Pokret). ${ }^{16}$ From their point of view, 'no national reconciliation in Serbia was possible without the rehabilitation of the Četniks and other non-communists, but their rehabilitation was impossible without undermining communist Yugoslavia' (Djokić 2002, 135). 
The first president of independent Croatia, Franjo Tuđman, promoted a narrative of national reconciliation, based on the idea that Croatian communists and Ustaša had fought for Croatian independence together in the WWII (see e.g., Banjeglav 2012). When he came to power, Tuđman's party decided to rename Zagreb's Trg Žrtava Fašizma (Square of the Victims of Fascism) to Trg hrvatskih velikana (Croatian Nobles Square) arguing that all Croats fought for the same cause, but under different flags (see e.g., Bellamy 2003; Pavlaković 2012). Even though Tuđman had officially embedded the Croatian anti-fascist tradition into the Constitution, ${ }^{17}$ his goal of national reconciliation effectively meant that anti-fascist commemorations were ignored and Ustaša ones tacitly tolerated (Pavlaković 2008, 178-79). Yugoslav symbols and remembrance days were forgotten, and anti-fascist monuments destroyed or vandalized. In Croatia, these processes opened the space for the whitewashing of the Ustaša movement (Pavlaković 2008).

\section{The impact of Europeanization on the politics of memory in Croatia and Serbia}

\section{Croatia: from anti-fascism to anti-communism}

In the pre-accession period, the Croatian politics of memory remained grounded in the narrative of the war for independence. Yet, despite the political consensus on the country's European future, the WWII continued to ideologically divide Croatia. The remembrance of the Holocaust and the anti-fascist values of Croatia became tools for identification with the EU. However, at the same time, the memory resolutions of the CoE (since 2006) and the EP (since 2008) on totalitarian regimes were utilized to assuage ideological divisions on the WWII (see Table 2).

The Homeland war (1991-1995) narrative was the main pillar of Croatian memory politics under Franjo Tuđman's rule in the post-war period. After Tuđman's death in 1999, his Croatian Democratic Union (Hrvatska demokratska zajednica - hereafter HDZ) lost popular support in elections and was replaced by a government of Social Democrats (Socijaldemokratska partija - hereafter SDP). As the cooperation with the ICTY was an element of EU conditionality, the party complied with the demand of the ICTY to deliver suspected Croat war criminals. After HDZ won the 2003 elections, it formed an alliance with the social democrats in order to pursue EU membership. The alliance was formalized in the so-called Pact for Europe. This in turn led to a renewed interest in Holocaust remembrance and in the commemoration of Jasenovac, at the site of the former Ustaša concentration camp.

Stjepan Mesić (the honorary president of the anti-fascist movement) was the first Croatian president to regularly attend the Jasenovac commemoration after the 1990s war. ${ }^{18}$ After the end of his mandate, it became customary for presidents to attend. The commemoration ceremony turned into a public display of the government's dedication to the anti-fascist legacy of Croatia and the remembrance of Serbian, Jewish and Roma victims of the Holocaust. In this sense, Jasenovac became 'a salient place not only to pay respect to the victims of the Holocaust, but also as a venue for the expression of Croatia's European values' (Stjepan Mesić 2017, Interview).

Significantly, the government also continued to support the Bleiburg commemoration which increasingly became a symbol of what was called by some 'the Red Holocaust' (see 


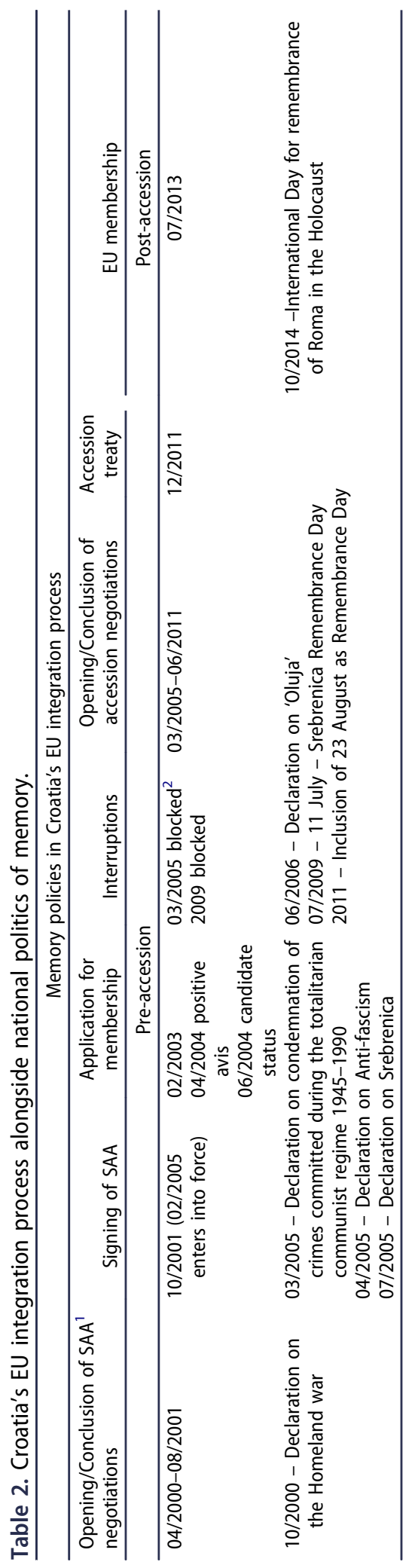


Prcela and Živić 2001). The resolutions on memory politics by the Croatian Parliament (Hrvatski Sabor - hereafter Sabor) also illustrate this double strategy of focusing on both anti-fascism as a way of getting closer to the EU while also stimulating anti-communist remembrance.

In 2005, the Sabor passed a Declaration on Anti-fascism that proposed an Anti-Fascist Remembrance Day, the plans for restoration of damaged anti-fascist monuments and a ban on the public display of fascist symbols. By confirming anti-fascism as a founding value of Croatia, the Declaration (Sabor 2005) recalls that 'the foundations of the European Union relate to the victory over fascism and joining the European commitment to democracy, freedom, tolerance, solidarity and the rejection of any forms of extremism and totalitarianism' (emphasis ours). However, in the text, the Sabor disconnects antifascism from its Yugoslav, cross-ethnic character. The declaration 'calls on government bodies and public institutions to objectively, comprehensively and impartially consider the historical period of World War II and anti-fascism in Croatia, not equating the anti-fascist movement with the ideology of communism' (Deklaracija Sabor 2005, emphasis ours). The purpose is to emphasize Croatian anti-fascism's link with the fight for independence in the 1990s, and to decouple it from the former Yugoslav communist regime.

Croatia was the first country of the former Yugoslavia to officially declare the former Yugoslavia as a 'totalitarian' state (Flere and Klanjšek 2014, 237). One month after the Council of Europe adopted the Resolution on communist crimes (2006), the HDZ and other right wing parties proposed a declaration on the 'Condemnation of crimes committed during the communist totalitarian regime in Croatia 1945-1990'. By denouncing communism, the declaration pays tribute to the innocent and helpless victims of Yugoslav and Croatian communism (...), which in the name of class struggle, dictatorship of the proletariat, "brotherhood and unity" and the promised "bright future," committed crimes against citizens of Croatia and Croats living outside the country' (Narodne novine 2006, 3).

After the EP adopted the resolutions on totalitarianism (2009b) and on the European day for Remembrance of its Victims (2008), Croatian nationalist parties such as the Croatian Party of Rights (Hrvatska stranka prava - hereafter HSP), supported by HDZ, repeatedly called for the adoption of similar declarations in Croatia. Two years before it became a EU member (2011), Croatia adopted 23rd of August as the European Day of Remembrance for the Victims of Totalitarian and Authoritarian Regimes. Supporters of the initiative emphasized that the EP in its recommendations invites all member states to adapt the time and manner of commemorating the victims of totalitarian regimes to its own history and tradition:

The fall of the totalitarian communist regimes in Central and Eastern Europe was not in all cases, even in the case of Croatia, accompanied by national and/or international investigations of crimes that these regimes committed. As a result, there is a low awareness by noncommunist countries, including the Croatian public about the crimes committed by totalitarian communist regimes. Sabor (2006)

After EU Accession, the Croatian politics of memory revolved around the projection of national collective memories, places of memory and symbols onto the EU level with an emphasis on dealing with Yugoslav past. The HDZ in particular worked uploaded national memories of the Homeland war, its ethno-national places of memory, victims as well as its war-veterans onto the EU level through the EP (Milošević 2017). In the 
HDZ's reading, the Homeland war was 'a war against Serbian fascists and at the same time against the communist totalitarian regime' (Davor Ivo Stier 2015, Interview). Moreover, the Croatian past in the former Yugoslavia is often compared to that of Central and Eastern European countries:

Since I come from Croatia, which was under communism for 45 years, I sympathize with and understand the fate of people who lived under the auspices of the totalitarian systems across Central and Eastern Europe. (Šuica 2014)

At the local level, a turn to anti-communist nationalism could be observed, and the public display of Ustaša insignia and the glorification of the fascist regime in mass-gatherings such are football matches, concerts, and commemorations were often tacitly tolerated (see Brentin 2016). In 2016, the Croatian Defence Forces (HOS) and right wing politicians unveiled a memorial plaque containing the controversial Ustaša slogan $\mathrm{Za}$ dom spremni ('Ready for the Homeland') near the former WWII concentration camp in Jasenovac. ${ }^{19}$ The move was heavily criticized, but Prime Minister Andrej Plenković downplayed the incident: 'The plaque does not honor a person from the Second World War, but was set up as a memorial to defendants who died in the 90s war' (Beta 2017). The lack of a strong condemnation of the use of Ustaša insignia in Jasenovac and elsewhere resulted in protests and the boycott of the 2017 and 2018 commemoration by the Jewish and Serbian community ${ }^{20}$ that opted to hold their own (separate) ceremonies.

Other recent political initiatives around the country sought to erase symbols of its Yugoslav past (see Jutarnji list 2018). The former minister for Culture, Zlatko Hasanbegović, for example, supported the renaming of a central square in Zagreb that was originally named after Josip Broz Tito (Trg Maršala Tita). ${ }^{21}$ Hasanbegović, a historian and a controversial figure in Croatian politics, is often criticized as 'historical revisionist', especially since he referred to anti-fascism as an 'empty word' (Milekić 2016). He strongly believes that 'the most important aspect of the past which defines our societies is not the Second World War, but the heritage of Yugoslav communism which we need to deal with' (Zlatko Hasanbegović 2017, Interview).

\section{Serbia's two-faced anti-fascism}

Throughout the 1990s, the Serbian interpretation of the Yugoslav wars emphasized Serbian victimhood. The Serbian people were victims of genocide and so-called ancient ethnic hatreds throughout their history, and in the 1990s, they had rightfully defended themselves. This narrative absolved Serb political elites of any kind of responsibility for war crimes. The process of European integration of Serbia challenged these narratives in two ways. On the one hand, cooperation with the ICTY was a prerequisite for starting membership talks. Second, the EU pressured Serbia to fully acknowledge the genocide in Srebrenica (see EP 2009a). The Serbian political establishment failed to fully comply with these demands. In 2010, Serbian Parliament adopted a Resolution on Srebrenica, but it failed to actually use the word genocide (see Dragović-Soso 2012). The pressure from the outside (including the United States and the EU) produced a counterreaction in Serbia.

The counterreaction also included a reinterpretation of the role of the Četniks in the WWII. The EU's anti-totalitarian resolutions were instrumental in legitimizing this narrative. In 2005, the Serbian parliament passed a controversial law on the rights of 
veterans of the WWII, equalizing the rights of both Četniks and Partisans (Službeni Glasnik 2005, 2006). After the EP had adopted the resolutions on anti-totalitarianism, nationalist parties such as the Serbian Renewal Movement (SPO) based their demands for the rehabilitation of the Četniks on documents of the CoE and the EP. Every year since 2009, the SPO has proposed a resolution on the Condemnation of crimes committed by the totalitarian communist regime and for the Day of Remembrance for the victims of totalitarian and authoritarian regimes. So far, these resolutions have not been adopted, but the example shows how the EP and CoE resolutions are utilized in attempts to rehabilitate the Četniks (See Table 3). In the debates in the Serbian Parliament, the EP's (2009b) resolution on European conscience and totalitarianism is repeatedly cited as an example for dealing with the past as the 'EU candidate countries and associated countries are invited to adopt and comply with it' (Aleksandar Čotrić, personal communication 2017). According to SPO, the Remembrance Day of 23rd of August $^{22}$ symbolizes the reconciliation of the Partisan and the Četnik past of Serbia sending a 'strong message to the descendants of Partisans and ravnogorci [Četniks]' who 'have to join hands in building the European future of Serbia, but also to correct grand historical injustices of our predecessors and for which these generations are not to blame' (Aleksandar Čotrić, personal communication 2014).

Serbian nationalist parties such as the SPO seek to rehabilitate country's ethnonationalist anti-fascism. To them, the former communists, the Socialist party of Serbia (Socijalistička partija Srbije - hereafter SPS), are the main obstacle for effectively dealing with the past:

Unfortunately, they do not understand that it is for their benefit to break with the past and the rule of Josip Broz and Slobodan Milošević, and to become a modern party of European Socialists. By continuing on this path, they are bound to become eternal prisoners of the past, a party tied to autocratic leadership and dogmatism inherent to previous regimes. (Čotrić, personal communication 2017)

The former communists on the other hand have reinterpreted the Yugoslav anti-fascist struggle as almost exclusively Serbian. ${ }^{23}$ In the view of the SPS and its leader Ivica Dačić, anti-fascism is a European value and one of the fundaments of the EU. ${ }^{24} \mathrm{He}$ sees a special role for Serbia: at the commemoration for the victims of Nazi occupation in Draginac, ${ }^{25}$ Dačić argued that Serbia contributed a lot more than 'some other countries' (i.e., Croatia, Germany, Italy, Austria) to European values. And, he added, it should not 'need to ask to be the part of the Union' - but 'it deserves to be Europe, because it made Europe here ${ }^{26}$ :

Immediately after the Second World War, those who committed this crime began to build a new Europe. We believe that Serbia is entitled to a new chance and therefore, not only that we should not forget, but we must constantly emphasize the sacrifices that we have given, because our victims are forgotten, because are history is distorted and the historically defeated nations of the First and Second World War now have become more important factors in the Balkans than Serbia and Serbian people. ${ }^{27}$

After the start of its accession negotiations with the EU in 2014, Serbia started to use its anti-fascist past as proof of its European identity. The government stresses country's contribution to the anti-fascist struggle, arguing that anti-fascism and freedom are fundamental values of Serbia. Serbian officials also seek to express anti-fascist values by attending transnational commemorations. The president of Serbia, for example, participated in the 


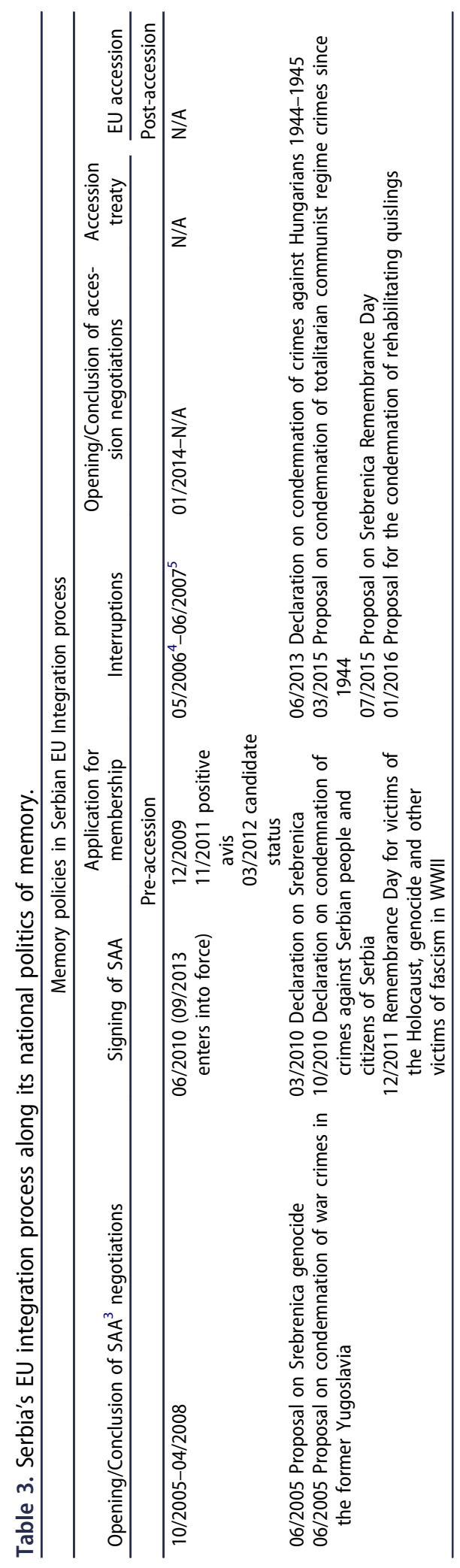


commemoration for 'the 70th anniversary of the capitulation of Nazi Germany in 1945' in Moscow. ${ }^{28}$ A year later, in October 2016, the City of Belgrade organized a celebration of the anniversary of its liberation. The city council officials argued that such a celebration was needed to prevent historical revisionism: 'We will not allow a revision of history. Some ideas of fascism now live in another form and represent a permanent threat to the stability of society. 29

Serbia applied for membership of the International Holocaust Remembrance Alliance in 2011. Around the same time, a Serbian delegation began to attend commemoration of the liberation of the concentration camp of Mauthausen in Austria, where many Yugoslavs had been imprisoned and killed. On the local level, there is also a renewed political interest in the commemoration of Holocaust. The Serbian political establishment participates in Holocaust commemorations organized by the Jewish community in Serbia. Commissions, plans and draft laws are being made to turn the former concentration camp 'Staro Sajmište' ${ }^{30}$ (the old fairground) into a memorial park (RFE, 2017). To this end, the Serbian government closely collaborates with the Council of Jewish municipalities (Savez jevrejskih opština), the Yad Vashem: World Holocaust Center, and the Simon Wiesenthal Centre. In 2011, Serbia adopted the 22nd of April as a Remembrance Day for the victims of the Holocaust, Genocide and Other Fascist Crimes of the WWII. This date marks the day prisoners broke out of Donja Gradina, one of the Jasenovac, Ustaša concentration camp sites. In 2017, both Serbian PM Aleksandar Vučić and Milorad Dodik president of Republika Srpska participated in a commemoration that was organized in Donja Gradina. ${ }^{31}$ Vučić stressed the role of Jasenovac in Serbian collective memory and the importance of memorializing Serb suffering and victimhood in WWII. ${ }^{32}$

The processes which took place in pre-accession Croatia with the renewal of the Holocaust remembrance are taking place 10 years later in Serbia. Combined with the attempts to incorporate the Četnik past into the Serbian anti-fascist tradition, this twofaced anti-fascism of the WWII is used to support Serbia's European identity and to reconcile the divergent views on the past.

\section{Conclusion}

The EP memory framework stresses the totalitarian and authoritarian character of former European political regimes, in contrast to the democratic and liberal present. While the anti-totalitarian resolutions were designed to reconcile the historical experiences of Western and Eastern Europe, their equalization of the legacies of fascism and communism have produced unintended consequences. On the one hand, the EP resolutions enable nationalist parties to legitimize the legal and symbolic rehabilitation of the movements that collaborated with the Axis. On the other hand, they equalize Nazism and its crimes, with the crimes committed by the Partisans in the immediate aftermath of WWII and Tito's regime. By consequence, the cross-ethnic struggle for liberation in WWII and the shared Yugoslav past are framed as totalitarian.

Our analysis shows that even though the EU memory framework is not a part of EU conditionality for acceding countries, it has had a significant impact on the politics of memory in both Croatia and Serbia. In the pre-accession period, both countries have expressed their European identity through memory politics with a renewed interested in the memorialization of the Holocaust and the anti-fascist struggle. However, in post- 
accession Croatia, there has been a continuation of Tuđman's politics of 'national reconciliation', resulting in a partial rehabilitation of the Ustaša past. Post-accession Croatian memory politics have also resulted in the uploading of national memories onto the European level.

In Serbia, right wing political parties have so far not managed to get political support for their memory politics of reconciling the Četnik and Partisan past in the name of European identity. The Serbian Parliament did not adopt their proposed resolution. It is not clear what will happen in the post-accession period, but what is certain is that Serbian memory politics in the post-accession period will have to fit into a framework that has already received memories uploaded by Croatia, including particular interpretations of the Yugoslav past. This will undoubtedly affect the further Enlargement process in the Western Balkans.

\section{Notes}

1. The Armenian genocide refers to series of forceful deportations and mass-killings of the Armenian population in the Ottoman Empire starting in 1915.

2. Holodomor (1932-1933) was an artificially induced famine in Soviet Ukraine in which several million of ethnic Ukrainians died from starvation.

3. Srebrenica is a small village in Bosnia-Herzegovina where, during the Yugoslav war (1995), around 8000 Muslim man and boys were victims of genocide perpetrated by the Army of Republic of Srpska.

4. In certain cases, this link between the object of resolution and its adoption as a proof of EU values is very linear as in the already mentioned resolution on Roma (see EP 2015b) which has a very strong human rights component.

5. Several politicians insisted on careful rephrasing of the resolution proposed by Swedish Goran Lindblad. For instance, the Croatian delegation was divided on this topic. Milorad Pupovac proposed a number of amendments pointing out differences among communist parties around Europe and in the Balkans, and the perils of future misinterpretations. Frano Matusić (HDZ) spoke about this resolution as a way of expressing sympathy for $(250,000$ ?) people killed in Bleiburg (see PACE Assembly 2006). In the immediate aftermath of the Second World War, Croatian soldiers and civilians associated with the Axis fled Yugoslavia. In what is known as a Bleiburg massacre, these persons were killed by the Yugoslav communists. The number of dead in the Bleiburg massacre is disputed among regional historians (see Footnote 9).

6. A number of international conferences have underlined the importance of this dimension: in June 2008, the Senate of the Czech Republic adopted a declaration on 'European conscience and communism' (the 'Prague Declaration'); in October 2009, the Baltic States, under the auspices of the President of the European Parliament, held the conference 'Europe 70 years after the Molotov-Ribbentrop Pact'. Another conference on 'Crimes of communism' was held in February 2010 by the Czech Institute for the Study of Totalitarian Regimes.

7. See Reconciliation of European Histories, an informal group of Members of the European Parliament. https://eureconciliation.eu/about/.

8. At that time, there were several Četnik movements. The one led by the general Mihailović was the strongest and was officially founded in Ravna Gora in 1942.

9. Demographer Vladimir Žerjavić estimates 45,000-55,000 Croats; Slavko Goldstein cites 20,000 Serbs, Slovenes and others alongside 50,000 Croats; Zdravko Dizdar notes that 62,000 have been identified by name from the territory of the NDH but adds that estimates have ranged from 60,000 to 600,000; former Ustaša official Vinko Nikolić claims 200,000 Croats; Vladimir Geiger has calculated approximately 80,000 total victims including all ethnic groups; and in a case where politics entered the fray, Croatian Prime Minister Ivo 
Sanader's former spokesperson Ratko Maček told reporters that 190,000 Croats were killed in Slovenia alone. We thank Vjeran Pavlaković for this comment.

10. An example of the political role played by local historians is The Memorandum of the Serbian Academy of Sciences and Arts (1986).

11. Although official registration due to its obvious Četnik insignia was not permitted, Šešelj’s movement merged with the National Radical Party (NRS), establishing the Serbian Radical Party (SRS) in 1991.

12. The Croatian Constitution (1991) recalls the 'establishing the foundations of state sovereignty during the course of the Second World War, by the decisions of the Antifascist Council of National Liberation of Croatia (1943)'. http://www.sabor.hr/fgs. axd?id=17074.

13. Although Tuđman visited Jasenovac in 1996, he never participated in the official commemoration. http://www.aimpress.ch/dyn/pubs/archive/data/199606/60623-001-pubs-zag. $\mathrm{htm}$. We thank our anonymous reviewers for this comment.

14. The plaque is attached to the external wall of the kindergarten in the village of Jasenovac. Field notes, Ana Milošević, April 2017.

15. The representatives of the Roma community were present at the commemoration. Field notes, Ana Milošević, April 2017.

16. In 2017, anti-fascist groups and left-wing parties of Croatia held several protests against renaming Marshal Tito Square, accusing the proponents of this initiative of an aggressive attempt to undermine Croatia's anti-fascist legacy. The name was abolished by a decision of the City Council in August, and the square was renamed Republic of Croatia Square.

17. The SPO wants to see this date changed and proposed 17 July for the Remembrance Day. This is the presumed date when, in 1946, the leading figure of the Četnik movement general Dragoljub Mihailović - was executed after being condemned to death by the Yugoslav regime.

18. Support for the SPS was steady since 2000 in all parliamentary elections (from $13 \%$ in 2000 to $14 \%$ in 2014 and $11 \%$ in 2016 ).

19. This reflects general attitudes in society, with people seeing the Yugoslav past as a positive experience. A survey conducted by IPSOS in 2011 shows that $71 \%$ of Serbs regret the dissolution of Yugoslavia and $20 \%$ think that Tito is the person who best represents Serbian values. (Nation building Serbia. Q: Which person (past or present) do you regard as the best representative of the values of the people of this country? p. 77).

20. B92. 2012. Šta je Dačić rekao u Dragincu. 15 October. http://www.blic.rs/vesti/politika/staje-dacic-rekao-u-dragincu/3vwre65. A commemoration is held annually in remembrance of 2950 civilians who were shot in Draginac (Serbia) between 11 and 17 October 1941 by the German troops.

21. Ibid.

22. Ibid.

23. Victory Day Commemoration in Moscow. Field notes, Ana Milošević, May 2015.

24. (City of Belgrade 2016). Nikodijević: Tradicija antifašizma najveće blago savremene civilizacije. Official web presentation, 20 October.

25. First run by the Nazis and later by the Croat Ustaša, Staro Sajmište in Belgrade was the site of a concentration camp during the Second World War. An estimate of the total number killed in the camp varies between 10,000 and 40,000 (see Jovan Byford. 2011. Staro Sajmište: The Place of Remembrance, Forgetfulness and Dispute. Belgrade: Center for Human Rights).

26. One of the detachments of the Jasenovac concentration camp was in Donja Gradina, situated just over the border in Bosnia-Herzegovina.

27. Field notes, Ana Milošević, April 2017.

28. SAA: Stabilization and Association Agreement.

29. EU postpones start of accession negotiations but adopts negotiation framework.

30. SAA: Stabilization and Association Agreement. 
31. SAA negotiations called off because Serbia's cooperation with the International Criminal Tribunal for the former Yugoslavia has not improved.

32. SAA negotiations resume, after Serbia committed to cooperating fully with the International Criminal Tribunal for the former Yugoslavia.

\section{Disclosure statement}

No potential conflict of interest was reported by the authors.

\section{Notes on contributors}

Ana Milosevic is a researcher at the University of Leuven (KU Leuven), Belgium. She is affiliated with the Faculty of Social Sciences at the KU Leuven, and the LINES Institute (Leuven International and European Studies). Her upcoming $\mathrm{PhD}$ thesis examines the impact of Europeanisation on memory politics in the Western Balkans.

Dr. Heleen Touquet is a professor at the University of Leuven as well as a visiting fellow at the Center for European Studies at Harvard University. She has written about post ethnic mobilisation in Bosnia, the framing of reconciliation and conflict-related sexual violence against men in various academic journals.

\section{ORCID}

Ana Milošević (D) http://orcid.org/0000-0003-4479-5397

Heleen Touquet (D) http://orcid.org/0000-0002-4624-0566

\section{List of interviews}

Anderson, B. 2006 1983. Imagined communities: Reflections on the origin and spread of nationalism. London: Verso.

Davor Ivo Stier. 2015. Audio recording. Brussels. June 30.

Stjepan Mesić. 2017. Audio recording. Zagreb. April 20

Zlatko Hasanbegović. 2017. Audio recording. Zagreb. April 24.

\section{Resolutions of the Council of Europe (CoE)}

1996. Resolution 1096: Measures to dismantle the heritage of former communist totalitarian systems

2006. Resolution 1481: Need for international condemnation of crimes of totalitarian communist regimes

\section{Resolutions of the European Parliament}

2006. 1956 Hungarian uprising and its historical meaning for Europe. P6_TA(2006)0454. October 24. 2007. On Estonia. P6_TA(2007)0215. May 24.

2008. European Day of Remembrance for the Victims of all Authoritarian and Totalitarian Regimes. September 23. P6_TA(2008)0439.

2009a. Srebrenica. P6_TA(2009)0028. January 15.

2009b. European conscience and totalitarianism. April 2. P6_TA(2009)0213.

2014. 25th Anniversary of the Fall of the Berlin Wall (debate), P8_CREREV. 
2015a. International Roma Day - anti-Gypsyism in Europe and EU recognition of the memorial day of the Roma genocide during Second World War. P8_TA(2015)0095. April 15.

2015b. Armenian genocide 100th anniversary. P8_TA(2015)0094. April 15.

\section{Resolutions in Croatia's Sabor}

Narodne novine. 2006. Deklaracija o osudi zločina počinjenih tijekom totalitarnoga komunističkog poretka u Hrvatskoj 1945. - 1990. godine (Declaration on condemnation of crimes committed during totalitarian communist regime in Croatia 1945-1990) 76/2006. July 10.

Sabor. 2005. Deklaracija o antifašizmu. Izvješća hrvatskoga sabora br. 423. Zagreb.

Sabor. 2006. Izvješća hrvatskoga sabora br. 450. Zagreb.

\section{Resolutions in Serbia's Narodna skupština}

Službeni glasnik Republike Srbije, 2006. Zakon o rehabilitaciji [The Law on Rehabilitation].

Službeni glasnik Republike Srbije. 2005. Zakon o pravima boraca, vojnih invalida i članova njihovih porodica [The Law on the rights of war veterans, disabled veterans and members of their families]. n.101.

Skupština Republike Srbije. 2014. Stenografske beleške, July, 17.

\section{References}

Assembly, P., Council of Europe (PACE). 2006. Official report of debates. Volume I. January 2326. doi:10.1016/j.jnutbio.2006.02.005

Assmann, A. 2008. Transformations between history and memory. Social Research 75 1: 49-72.

Banjeglav, T.. 2012. Conflicting memories, competing narratives and contested histories in croatia's post-war commemorative practices. Croatian Political Science Review 49 5: 7-31.

Bellamy, A.J. 2003. The formation of Croatian national identity. A centuries-old dream. Manchester: University Press.

Beta. 2017. Plenković: O spomen ploči u Jasenovcu još će se razgovarati. June 23. http://rs. n1info.com/a278111/Svet/Region/Plenkovic-O-spomen-ploci-u-Jasenovcu-ce-se-jos-razgo varati.html.

Brentin, D. 2016. Ready for the homeland? Ritual, remembrance, and political extremism in Croatian football. Nationalities Papers 44 6: 860-76. doi:10.1080/00905992.2015.1136996

Calligaro, O., and F. Foret. 2012. La mémoire européenne en action. Acteurs, enjeux et modalités de la mobilisation du passé comme ressource politique. Politique Européenne 37: 18-43. doi:10.3917/poeu.037.0018

City of Belgrade. 2016. Nikodijević: Tradicija antifašizma najveće blago savremene civilizacije. October 20. http://www.beograd.rs/lat/beoinfo/1728895-nikodijevic-tradicija-antifasizma-naj vece-blago-savremene-civilizacije/.

Connerton, P. 1989. How societies remember. Cambridge: Cambridge University Press.

Coromines i Guixe, J. 2016. Introduction. In Past and Power. Public Policies on memory. Debates, from Global to Local, ed J. Guixe I Coromines, Barcelona: UBe.

Djokić, D. 2002. The Second World War II: Discourses of reconciliation in Serbia and Croatia in the late 1980s and early 1990s. Journal of Southern Europe and the Balkans Online 4 2: 127-40. doi:10.1080/1461319022000021585

Dragović-Soso, J. 2012. Apologising for Srebrenica: The declaration of the Serbian parliament, the European Union and the politics of compromise. East European Politics 28 2: 163-79. doi:10.1080/21599165.2012.669731

Flere, S., and R. Klanjšek. 2014. Was tito's yugoslavia totalitarian. Communist and PostCommunist Studies 47 2: 237-45. doi:10.1016/j.postcomstud.2014.04.009 
Frucht Levy, M. 2009. 'The last bullet for the last serb': The ustaša genocide against serbs: 1941-1945. Nationalities Papers 37 6: 807-37.

Hobsbawn, E., and T. Ranger eds. 1983. The Invention of Tradition. Cambridge: Cambridge University Press.

Jambrek, P., ed. 2008. Crimes committed by totalitarian regimes. Ljubljana: Slovenian Presidency of the Council of the European Union.

Jelin, E. 2003. State Repression and the Labors of Memory. Minneapolis: University of Minnesota. Jović, D. 2004. 'Official memories' in post-authoritarianism: An analytical framework. Journal of Southern Europe and the Balkans 6 2: 97-108. doi:10.1080/1461319042000242001

Jović, D. 2009. Yugoslavia: A State That Withered Away. West Lafayette, IN: Purdue University Press. Jutarnji list. 2018. Hasanbegović o zaključku vijeća za suočavanje s prošlošću. March 1. https:// www.jutarnji.hr/vijesti/hrvatska/hasanbegovic-o-zakljucku-vijeca-za-suocavanje-s-prosloscuto-je-vrsta-intelektualng-nedonosceta-koje-je-pretenciozno-nazvano-dokumentom-dijaloga/ $7083183 /$

Karge, H. 2009. Mediated remembrance: Local practices of remembering the Second World War in Tito's Yugoslavia. Journal European Review of History: Revue Européenne D'histoire 16 1: 49-62. doi:10.1080/13507480802655394

Katz, D. 2015. Is Eastern European 'Double Genocide' revisionism reaching museums? Dapim: Studies on the Holocaust 30 3: 191-220.

Kucia, M. 2016. The Europeanization of holocaust memory and Eastern Europe. East European Politics \& Societies and Cultures 30 1: 97-119. doi:10.1177/0888325415599195

Kuljić, T. 2006. Kultura sećanja. Belgrade: Čigoja štampa.

Kuljić, T. 2011. Smrt kod levice i desnice: Prilog kritici antitotalitarne tanatologije. Filozofia I Društvo 22 4: 111-26.

Langenbacher, E. 2003. The Return of Memory: New discussions about German suffering in World War II. German Politics \& Society 2 3: 74-88.

Leggewie, C. 2008. A Tour of the battleground: The seven circles of pan-European memory. Social Research 75 1: 217-34.

Littoz-Monett, A.. 2012. The EU politics of remembrance: Can Europeans remember together? West European Politics 35 5: 1182-202. doi:10.1080/01402382.2012.706416

Milekić, S. 2016. Hrvatski aktivisti kritiziraju novog 'reakcionarnog' ministra kulture. Balkan Insight, January 28. http://www.balkaninsight.com/rs/article/hrvatski-aktivisti-kritizirajunovog-reakcionarnog-ministra-kulture-01-27-2016.

Milošević, A. 2017. Back to the future, forward to the past: Croatian politics of memory in the European parliament. Nationalities Papers 45 5: 893-909. doi:10.1080/00905992.2017.1289368

Milošević, S. 1989. Gazimestan speech. http://www.slobodan-milosevic.org/spch-kosovo1989.htm.

Mink, G. 2016. Politics and Memory in Post-communist Europe. In Past and Power. Public Policies on Memory. Debates, from Global to Local, ed J. Coromines i Guixe, 44-56. Barcelona: UBe.

Montero, C. Carlos 2010. Study on How the Memory of Crimes Committed by Totalitarian Regimes in Europe is Dealt with in the Member States. Madrid: Institute for Public Goods and Policy.

Morsch, G. 2012. a Comprehensive Revaluation of European History? Developments, Tendencies and Problems of a Culture of Remembrance in Europe. In the Conference Reader If Not Now, When? The Future of the Site of the Old Fairground 'Staro sajmište, prepared by G. Maria, M. Bogdanović, K. Wolfgang, and M. James, 118-35. Belgrade: Heinrich Böll Stiftung, Savez Jevrejskih Opština Serbie and Stiftung EVZ.

Neumayer, L. 2015. Integrating the Central European past into a common narrative: the mobilizations around the 'crimes of communism' in the European parliament. Journal of Contemporary European Studies 23 3: 344-63. doi:10.1080/14782804.2014.1001825

Niebuhr, R. 2016. Between victors and vanquished: Wehrmacht prisoners of war in Yugoslavia. The Journal of Slavic Military Studies 29 1: 139-59. doi:10.1080/13518046.2016.1129880

Pakier, M. and B. Strath. 2010. A European memory?: Contested histories and politics of remembrance. New York: Berghahn. 
Pavlaković, V. 2008. Flirting with fascism. The Ustasa Legacy and Croatian politics in the 1990s. In Una storia balcanica: Fascismo, comunismo e nazionalismo nella Jugoslavia del Novecento, ed L. Bertuccelli and M. Orlić, 178-97. Verona: Ombre corte.

Pavlaković, V. 2010. Deifying the defeated: Commemorating bleiburg since 1990. L'Europe En Formation 357: 125-47. doi:10.3917/eufor.357.0125

Pavlaković, V. 2012. Conflict, Commemorations and Changing Meanings: The Mestrovic Pavilion as a Contested Site of Memory. In Confronting the Past: European experiences, ed D. Pauković, V. Pavlaković, and V. Raos, 317-52. Zagreb: Political Science Research Centre.

Prcela, J.I., and D. Živić. 2001. Hrvatski Holokaust. Zagreb: Hrvatsko društvo političkih zatvorenika.

Probst, L. 2003. Founding myths in Europe and the role of the holocaust. New German Critique 90: 45-58. doi:10.2307/3211107

Prutsch, M.J. 2013. European historical memory: Policies, challenges and perspectives. Luxembourg: European Union Publication office.

Radio Free Europe. 2017. Izrađen Nacrt zakona o Starom Sajmištu. September 23. https://www. slobodnaevropa.org/a/28753154.html.

Radonić, L. 2012. Croatian politics of past - just one more post-communist case study? Istorija XX Veka 1: 203-15.

Ravančić, Martina, G. 2009. Izručenja i sudbine zarobljenika smještenih u savezničkim logorima u svibnju 1945. Časopis Za Suvremenu Povijest 41 2: 391-416.

Rostoks, T. 2011. Debating 20th Century History in Europe: The European Parliament and the Parliamentary Assembly of the Council of Europe Compared. In The Geopolitics of History in Latvian-Russian Relations, ed M. Nils, 191-219. Riga: Academic Press of the University of Latvia.

Roth, M. 2009. Bilateral Disputes between EU member states and Russia. CEPS Working Document No. 319/August.

Suica, D. 2014. European Parliament. In 25th anniversary of the Fall of the Berlin wall (debate), P8_CRE-REV(2014)11-12. 